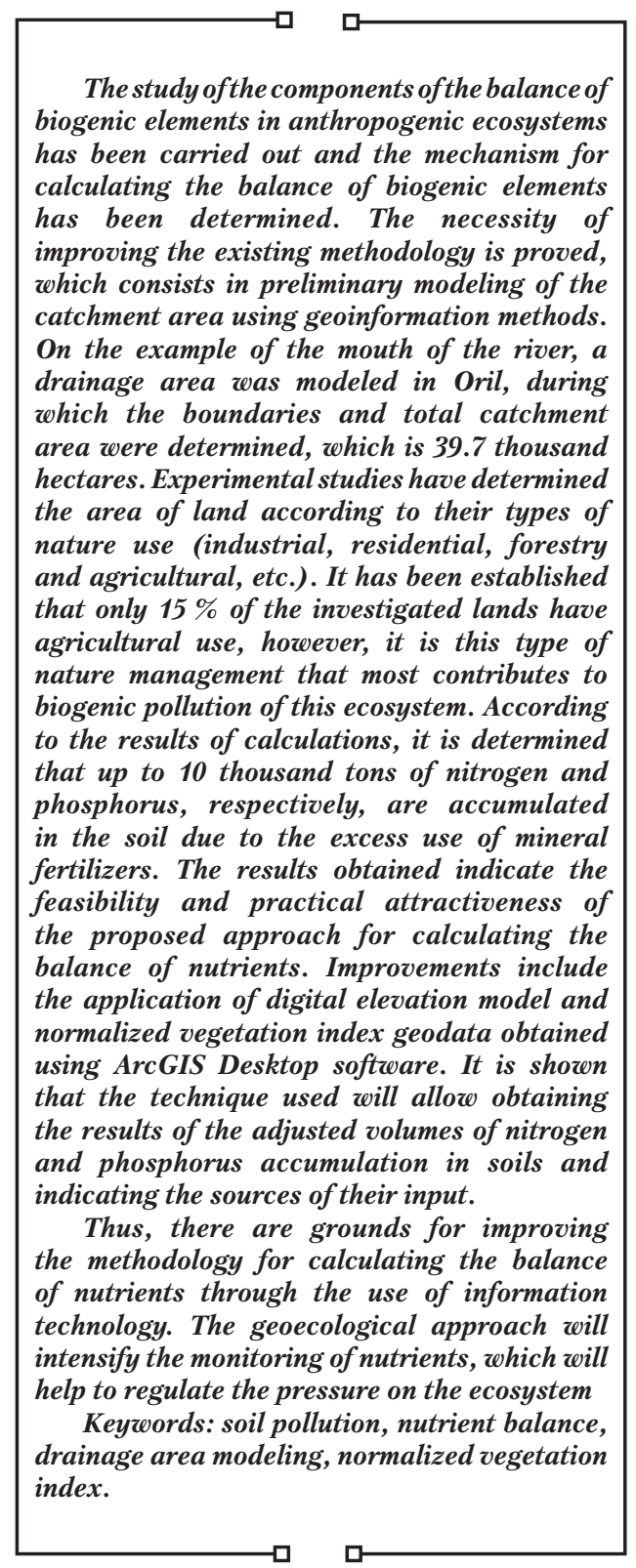
nature use (industrial, residential, forestry biogenic pollution of this ecosystem. According to the results of calculations, it is determined that up to 10 thousand tons of nitrogen and (the the proposed approach for calculating the balance of nutrients. Improvements include the application of digital elevation model and ormalized vegetation index geodata obtained using ArcGIS Desktop software. It is shown and phosphorus accumulation in soils and dicating the sources of their input. technology. The geoecological approach zeill intensify the monitoring of nutrients, which will drainage area modeling, normalized vegetation index.

\title{
IMPROVEMENT OF THE METHODOLOGY FOR THE ASSESSMENT OF SOIL BIOGENIC POLLUTION THROUGH THE USE OF GEOECOLOGICAL APPROACHES AND THE USE OF INFORMATION TECHNOLOGIES
}

\author{
Iryna Omelych \\ Postgraduate Student* \\ Natalia Neposhyvailenko \\ Corresponding author \\ $\mathrm{PhD}$, Associate Professor* \\ E-mail: nna2013@ukr.net \\ O leksandr Z berovskyi \\ Doctor of Technical Sciences, Professor* \\ Iryna Korniienko \\ $\mathrm{PhD}$, Associate Professor \\ Department of Biotechnology \\ National Aviation University \\ Liubomyra Huzara ave., 1, Kyiv, Ukraine, 03058 \\ Dniprovsk State Technical University \\ Dniprobudivska str., 2, Kamianske, Ukraine, 51918
}

*Department of Ecology and Environmental Protection

\section{Introduction}

Nutrients (compounds of nitrogen and phosphorus) are among the key nutrients that stimulate the development of autotrophic aquatic organisms and provide support in the water for primary production and accumulation of organic matter. An increase in the content of nutrients in surface water bodies leads to the uncontrolled development of higher aquatic plants and algae. As a result, an undesirable violation of the balance of organisms in a water body occurs, which is one of the main reasons for their unsatisfactory quality [1].

As noted [2], the low quality of natural waters leads to a decrease in biological diversity and productivity of water bodies as a result of eutrophication of freshwater ecosystems.
Pollution of surface water bodies, according to the studies of the authors [3], leads to a deterioration in the quality of groundwater, soils and ecosystems dependent on them. As noted in [4], the unsatisfactory quality of natural waters causes the spread of diseases when using such waters with centralized and decentralized water supply for drinking and household needs over large areas and distances from pollution sources.

Consequently, the impact of nitrogen and phosphorus compounds on the environment is multifaceted, therefore, studies aimed at improving methods for determining the volumes and sources of nutrient input should be considered relevant. In addition, in order to prevent secondary pollution of the environment, it is advisable to predict the nature of the spread and places of localization of pollutants. 


\section{Literature review and problem statement}

The concentration of nutrients in natural waters, in particular small rivers, is usually low and is in the range: $\mathrm{NH}_{4}^{+}-$ $0.361 .43 \mathrm{mg} / \mathrm{l} ; \mathrm{NO}_{3}^{-}-0.02-0.50 \mathrm{mg} / \mathrm{l} ; \mathrm{PO}_{4}^{3-}-0.010 .46 \mathrm{mg} / \mathrm{l}$ (for example, Oril). The actual content of nutrients fluctuates throughout the year and depends on many local factors (regulation of rivers, their shallowing, etc.) and global (spring floods, global warming, etc.), as noted [5]. In [6], it is shown that biogenic elements enter natural waters as a result of decomposition of the remains of animal and plant organisms, with river runoff, atmospheric precipitation, and wastewater. The overwhelming amount of nitrogen and phosphorus entering ecosystems is primarily due to anthropogenic activities, in particular industrial, housing and communal and agricultural water use, as noted by the authors [7]. Thus, according to the National Report on the Quality of Drinking Water and the State of Drinking Water Supply in Ukraine [8], in 2018, 5,210 million $\mathrm{m}^{3}$ of wastewater was discharged into surface water bodies. Of the total amount of discharges from industrial enterprises, 3284 million $\mathrm{m}^{3}$ were received, housing and utilities industry - 1513 million $\mathrm{m}^{3}$, agricultural enterprises 349.6 million $\mathrm{m}^{3}$.

However, it should be noted that these studies lack data on nutrient inputs with reference to drainage basins, natural conditions, and anthropogenic factors. The migration and accumulation of compounds of nitrogen, phosphorus and other substances largely depend on these local factors. This means that it is not determined how the pollution process proceeds, and from a practical point of view, it leads to difficulties associated with predicting this phenomenon.

The most significant contribution to the pollution of ecosystems with biogenic elements occurs as a result of active agricultural activities $[9,10]$. The main problem, according to the authors [11, 12], is the uncontrolled use of mineral fertilizers. In [13], the results of studies are given, according to which it was found that along with the main biogenic elements of fertilizer, additional substances are supplied to the soils. Such impurities in the form of salts of heavy metals, organic compounds, radioactive isotopes lead to negative effects on the environment, flora and fauna, agricultural products and human health. Therefore, it is extremely necessary to control the transportation, storage, use and disposal of organic and mineral fertilizers in agriculture.

Despite the practical significance of the results of scientific research on the impact of agricultural activities on biogenic soil contamination, the aspect of monitoring the use of fertilizers has not been considered.

After all, the most difficult link in the chain of transformation of biogenic elements is monitoring the use of mineral and organic fertilizers in areas bounded by watersheds. Getting on agricultural land, a significant part of nitrogen-containing compounds and phosphorus remains in the soil, forming their excess in the ecosystem. This process is due to excessive application of mineral fertilizers and incomplete assimilation by plants. In addition, at the local level, hydrogeological conditions and relief-forming factors can have a significant impact. So, it becomes necessary to determine the zone of potential accumulation of biogenic substances and determine the type of nature management for it, associated with crop rotations of agricultural land, afforestation of the territory, the presence of other natural and anthropogenic factors.

The control of the content of nutrients in ecosystems is carried out using classical monitoring approaches. According to the standard scheme, monitoring consists of sampling, carrying out chemical analysis and comparing the concentrations of research elements with maximum permissible [14] or background concentrations [15]. However, such monitoring is quite labor-intensive and materially expensive, since it has to be performed constantly and take into account a large number of local factors [16] (type of land use, seasonality, climatic indicators, etc.), as noted [17, 18]. However, according to the definition given in the Nature Management Dictionary [19], an integral component of monitoring is the spatial aspect (from background to impact) and the methods of its implementation: space, aviation, biological [20], etc. A similar concept of ecosystem monitoring is being developed by a number of scientists [21], using aerospace methods for observing ecosystems [22], methods of numerical modeling [23], interdisciplinary scenario-modeling [24] and a generalized integrated approach [25]. However, in support of this concept, the corresponding methods of data collection, modeling and forecasting of the process of distribution of nutrients from the sources of their supply to recipients are not given.

Therefore, there is reason to consider imperfect and outdated studies based only on the classical methods of balance equations [7], which require additional determination of the factors that determine the introduction/removal of nutrients within a separately defined catchment area. And the methods of remote sensing of the earth [26, 27] and geoinformation modeling $[28,29]$ necessitate the modeling of the catchment area, separation of sources and assessment of the intensity of potential biogenic pollution. Such innovations to the classical methods of balance calculations will allow at the global and local level to assess the degree of biogenic pollution of ecosystems and make recommendations for their balanced use.

\section{The aim and objectives of research}

The aim of research is to improve the methodology for assessing soil biogenic pollution by applying geoecological approaches. This will make it possible to clarify the balance components of nitrogen and phosphorus in soils at the territorial level and will allow controlling the application of mineral fertilizers, which will help regulate the load on the ecosystem.

To achieve this aim, the following objectives were solved:

- to develop a methodology for obtaining initial geodata for calculating the balance of nutrients, using geoinformation technologies and tools of the ArcGIS Desktop software;

- to determine the volumes of soil pollution with nutrients based on balance calculations, refined by applying geoecological approaches.

\section{Materials and methods of research}

4. 1. Characteristics of the research object, output data and software used in the experiment

The studies were carried out for the territory of the Petrykivka district of the Dnipropetrovsk region (Ukraine), the map of which is shown in Fig. 1, bordering on Dnipro, Tsarychanka, Krynychky, Verkhniodniprovsk, Magdalynivka district of Dnipropetrovsk region, Kobeliaky district of Poltava region. 

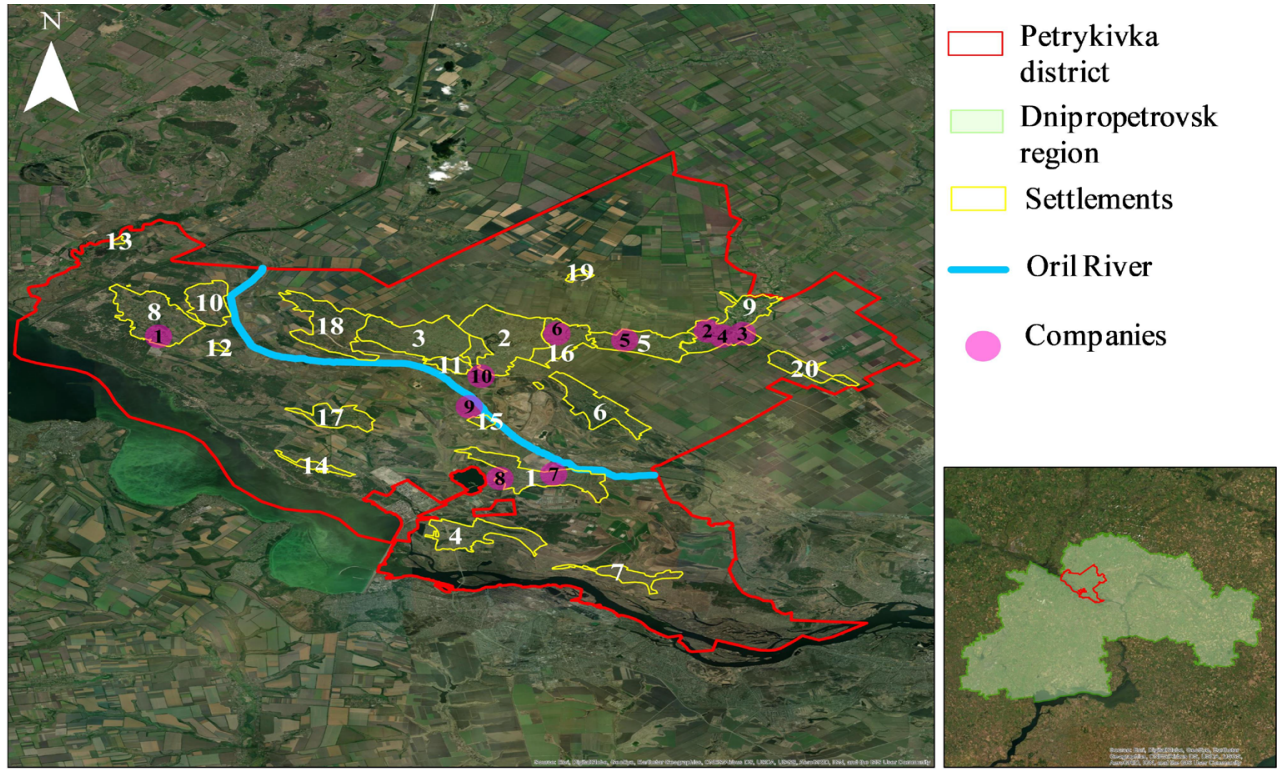

$\begin{array}{llll}0 & 5 & 10 & 20 \mathrm{Km}\end{array}$

Fig. 1. Map of the study area - Petrykivka district of Dnipropetrovsk region (Ukraine): Settlements (villages):

1-Yelyzavetivka; 2 - Petrykivka; 3 - Ivanivka; 4 - Kurylivka; 5 - Khutirske; 6 - Loboikivka; 7 - Mykolaivka; 8 - Shulhivka;

9 - Chaplynka; 10 - Sorochyne; 11 - Kleshnivka; 12 - Sudivka; 13 - Plaveshchyna; 14 - Kulishi; 15 - Sotnytske; 16 - Mala Petrykivka; 17 - Radisne; 18 - Hrechane; 19 - Kulisheve; 20 - Ulyanivka; Companies: 1 - Agroprominvest LLC; 2 - Vesna LLC;

3 Ekofield LLC; 4 - Alfa-Agro LLC; 5 - Vidrodzhennia; 6 - Vocational school 79; 7 Oril-Leader CJSC; 8 - Dniprovsky LLC; 9 - Petrykivka Breeding Farm LLC; 10 Petrykivka Fish farm CJSC

On the territory of the Petrykivka district there are 20 rural settlements and more than 30 enterprises and producers, mainly of the food industry and processing of agricultural products. The largest commodity producers in the region are Oril-Leader CJSC, Dniprovsky LLC, Alfa-Agro LLC, Ekofield LLC, Vidrodzhennia, Petrykivka Fish farm CJSC, Agroprominvest LLC, Petrykivka Breeding Farm LLC, Vesna LLC and others.

The relief of the region is flat, in some places there are beams, ravines, swamps. In the bowels of the earth, deposits of coal, natural gas, deposits of building clays and sand were found [30]. The modern landscape diversity of the Petrykivka district is formed mainly by anthropogenic types of landscapes, negatively affects the ecological state of adjacent natural and semi-natural complexes. The territory is washed by the waters of the Dnipro River and Dnipro reservoir. The Oril River flows through the region, which has the main tributary of the Chaplynka River. Unlike Dnipro River, Oril River is a small river and belongs to the category of relatively clean water bodies, since its basin does not border on the industrial agglomerate. Oril is one of the least transformed rivers of the steppe zone of Ukraine. The river flows through the territory of the Dnipro lowland, which is composed of a thick layer of sedimentary rocks. Oril River basin has a developed hydrographic network, which includes 127 tributaries of various orders (more than $10 \mathrm{~km}$ long), as well as a large number of lakes, oxbows and swamps [31].

Modeling of conditionally closed ecosystems, within which balance calculations are performed, was carried out using licensed software ArcGIS Desktop 9.2 using a certain set of tools from the ArcCatalog, ArcMap, Spatial Analyst applications. The initial data for modeling were digital maps, a digital elevation model and multispectral satellite images of the research area from open electronic resources.
4. 2. Methodology for calculating the balance of nutrients in soils

To calculate the balance of nutrients, a balance equation is proposed (1):

$$
B=\sum_{i, j=1}^{n, m} N_{i j}
$$

where $N$ - balance amount of biogenic elements received from a certain component of the ecosystem, t/year .; $n$ - biogenic element (nitrogen, phosphorus); $m$ - components of the ecosystem; for a given research area - agricultural land, industrial facilities, housing and communal services, natural factors.

4. 2. 1. Methodology for calculating the balance of nutrients from the contribution of agricultural land

The balance amount of nutrients from agricultural activities is primarily due to the use of mineral fertilizers applied to agricultural lands, their subsequent removal and losses. The calculation was made according to the formula (2), according to the methodology for compiling water protection zones of the rivers of Ukraine [7]:

$$
N_{a g_{i}}=\frac{S_{i} \times W_{f_{i}}-\left(W_{c_{i}}+W_{b_{i}}\right)}{1000},
$$

where $N_{a g_{i}}$ - balance amount of the i-th nutrient entered ecosystems as a result of agricultural activities, t / year;

$S_{i}$ - area of agricultural land on which a certain type of mineral fertilizers is used within the catchment area, hectares;

$W_{f_{i}}-$ amount of applied mineral fertilizers, kg;

$W_{c,}$ - total removal of nutrients from agricultural land from natural factors, $\mathrm{kg}$; 
$W_{b_{i}}$ - total removal of nutrients from agricultural land as a result of fertilizer losses, $\mathrm{kg}$.

Of nutrients from the contribution of industrial facilities the industry uses in production processes natural water from surface and underground sources, which have an initial mineralization, including nitrates and phosphates. On average, for the Petrykivka district, the content of nitrates in natural waters varies $0-3 \mathrm{mg} / \mathrm{l}$, phosphates $0-5 \mathrm{mg} / \mathrm{l}$ [31]. Removal of biogenic elements is formed due to the norms of maximum permissible wastewater discharges regulated for each enterprise. In addition, it is necessary to take into account the specifics and standards for the consumption of natural waters in the production process of the relevant industries, the available actual data on the volumes of water used, the volumes of wastewater discharges. The balance amount of nutrients supplied to ecosystems from industrial production is calculated by the formula (3):

$$
N_{n o_{i}}=\left(\left(V^{c} \times c_{i}^{c}\right)-\left(V^{n} \times c_{i}^{n}\right)\right) \times 10^{-9},
$$

where $N_{n 0_{i}}$ - balance amount of the i-th nutrient entered ecosystems as a result of industrial activity, $t$ / year;

$V^{c}$ - volume of waste water from the production process, $\mathrm{m}^{3} /$ year;

$c_{i}^{c}$-concentration of the $\mathrm{i}$-th nutrient in wastewater, $\mathrm{mg} / \mathrm{m}^{3}$;

$V^{n}-$ volume of water used in the production process, $\mathrm{m}^{3} /$ year;

$c_{i}^{n}-$ concentration of the $\mathrm{i}$-th nutrient in natural waters, $\mathrm{mg} / \mathrm{m}^{3}$.

4.2.3. Methodology for calculating the balance of nutrients from the contribution of housing and communal services

Housing and communal services are an integral part of the water management complex, since the rural population uses mainly natural water from underground sources for household needs and irrigation of household plots. Natural waters used in households with an initial mineralization and a certain content of nutrients. At the same time, the discharge of household wastewater in rural areas is mainly decentralized. So, in calculating the balance of biogenic substances received from housing and communal services, the volumes of natural water used by the population must be calculated taking into account the concentration of nitrates and phosphates in natural waters. When assessing the expenditure components, it is necessary to use the norms of household and drinking water consumption, taking into account the coefficient of daily unevenness, which are adopted in accordance with building codes and regulations. What is the cost of the initial components of balance calculations, it is also necessary to take into account the housing and communal sector as a source of the removal of nutrients into ecosystems with domestic wastewater. Taking into account the Methodology for compiling water protection zones of rivers in Ukraine [7], with domestic wastewater, $0.355 \mathrm{~kg} /$ year and $0.277 \mathrm{~kg} /$ year of nitrogen and phosphorus, respectively, from one person enter ecosystems. The balance amount of biogenic substances that got into ecosystems from housing and communal services is calculated by the formula (4):

$$
N_{h s_{i}}=\left(\begin{array}{l}
c_{i}^{m} \times n-c_{i} \times \\
\times\left(\begin{array}{l}
n^{\prime} \times q_{n} \times K_{h} \times \\
\times K_{d} \times T
\end{array}\right) \times 10^{-9}
\end{array}\right) \times 10^{-3},
$$

where $c_{i}^{m}$ - potential concentration of the $\mathrm{i}$-th nutrient from one person, $\mathrm{kg} /$ year;

$n$ - number of population, people;

$c_{i}^{n}-$ concentration of the $\mathrm{i}$-th nutrient in natural waters, $\mathrm{mg} / \mathrm{m}^{3}$;

$c_{i}^{n}$ - number of the population depending on the norms of water consumption for settlements, people;

$q_{n}$ - average daily water consumption rate, l/day;

$K_{h}, K_{d}$ - coefficients of hourly and daily irregularity of water consumption;

$T$ - time, days.

4. 2. 4. Methodology for calculating the balance of nutrients from the contribution of natural factors

The amount of biogenic elements in natural ecosystems is determined by their background values, and the input balance components of nitrates and phosphates are conventionally ignored in the calculations (5). This is due to the microvolumes of natural input of biogenic elements into ecosystems is determined by natural conditions and terrain. Natural filters can be taken as the output components of the balance of nutrients, in particular phosphorus, from the contribution of natural factors. According to the Methodology for the compilation of water protection zones of Ukrainian rivers [7], forests, meadows (hayfields), swamps and forest belts, which have the ability to absorb phosphorus, are natural filters. The amount of phosphorus absorption by natural filters is given in Table 1 .

Table 1

Phosphorus absorption with natural filters [7]

\begin{tabular}{|c|c|}
\hline Natural filter & $\begin{array}{c}\text { Volumes of natural absorption of phos- } \\
\text { phorus, } \mathrm{t} / \text { ha per year }\end{array}$ \\
\hline Forest & 0,031 \\
\hline Meadows (haymaking) & 0,004 \\
\hline Reed Swamp & 0,180 \\
\hline forest belts & 0,017 \\
\hline
\end{tabular}

The calculation of the balance of nutrients from the contribution of natural factors is carried out according to the formula (5):

$$
N_{n f_{i}}=0-\left(S_{i} \times k_{i}\right)
$$

where $S_{i}$ - area of the natural filter, ha; $k_{i}$ - volumes of natural absorption of nutrients, $\mathrm{t} / \mathrm{ha}$ per year.

4. 3. Methodology for obtaining initial geodata for calculating the balance of nutrients using geoinformation technologies

The calculation of the balance of biogenic elements provides for the determination of certain territorial boundaries in order to model the conditional closed ecosystems, within which balance calculations are performed. This modeling was done using ArcGIS Desktop software using a specific set of tools from the ArcCatalog, ArcMap, Spatial Analyst applications, as well as the output digital maps of the research area from open electronic resources. A graphical model of the sequence of operations performed, tools used, intermediate and final results is shown in Fig. 2. 
Block II

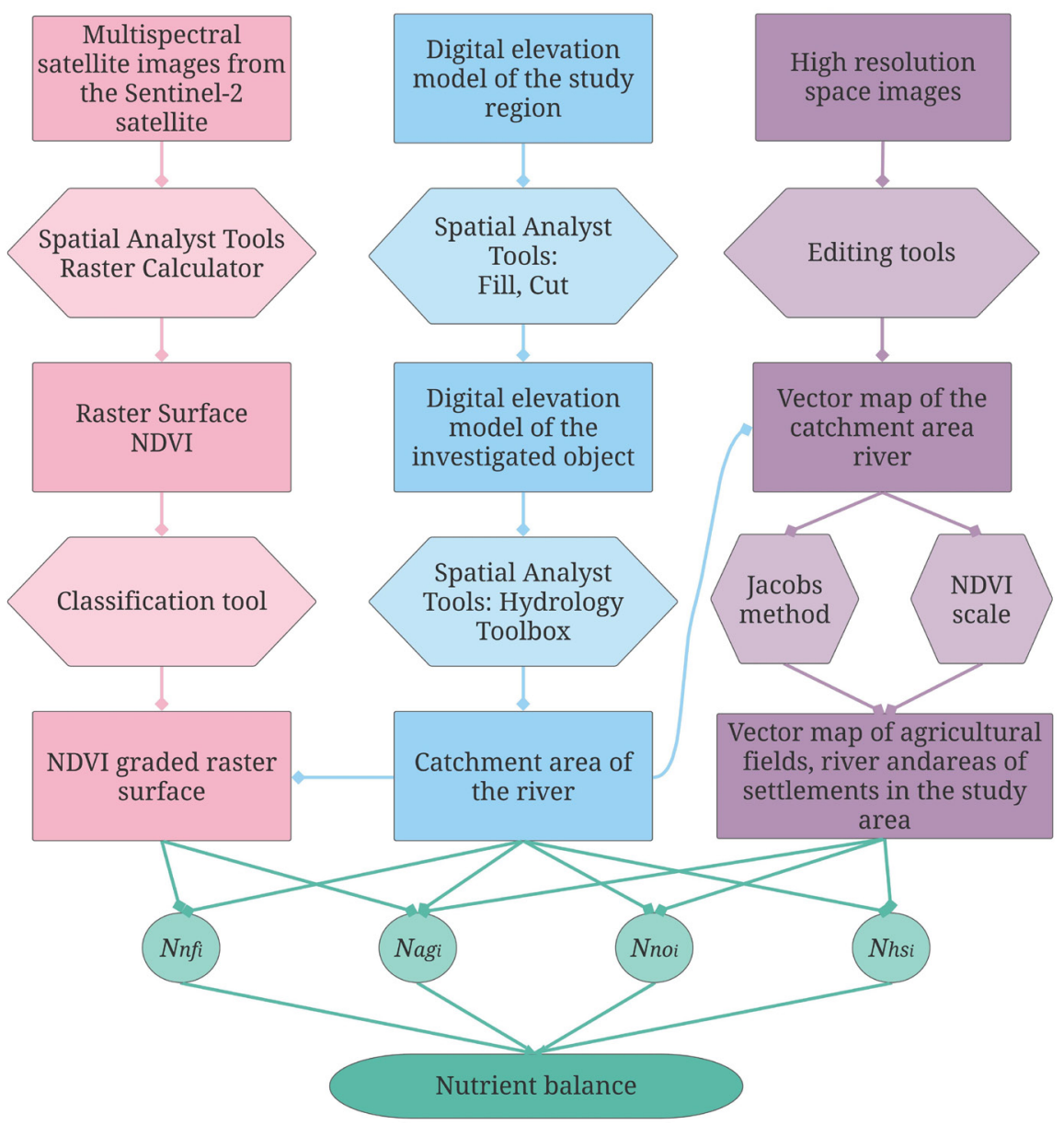

Fig. 2. A graphical model for obtaining the initial data for calculating the balance of nutrients using geoinformation methods

The given model consists of three blocks.

The first block of the model presents a sequence of operations for defining the catchment area of the study area. For this, a digital elevation model (DEM) of the study area with a resolution of $90 \mathrm{~m} /$ pixel, obtained from the open electronic resource Mapgroup [26], is used. The output DEM is processed by ArcGIS Desktop tools, namely Spatial Analyst Tools, and the DEM of the study object is generated. Based on the DEM of the research object, it is necessary to model the river basin and its water intake area within the research object. The first step in creating a river basin is to fill in the false basins on the DEM (Fill). Next, creating a raster of Flow Direction and Snap Pour Point, then playing back Flow Accumulation. As a result, by combining the referenced points of the mouth and the total runoff, the water intake area of the river was obtained. The modeling should take into account all tributaries and other significant water bodies in order to further separate them from the general catchment area. In this step, let's use the Hydrology tool, the Spatial Analyst of the ArcGIS 9.2 software.

The second block of the model presents the sequence of operations for obtaining the Normalized Difference Vegetation Index (NDVI) surface, which allows to visually assess the density and intensity of vegetation growth within the study area. For this, multispectral satellite images of the red and infrared spectrum are used from the Sentinel-2 satellite, which are freely available on the official website of the US Geological Survey [27]. The Spatial Analyst Tools "Raster
Calculator" models NDVI raster surfaces. Geodata of channels B4 and B8 of the survey spectra with the indication of the data type Float (fractional numbers) are selected as parameters for calculations. In the expression field, it is necessary to write the formula for calculating the NDVI. In the ArcGIS environment, the formula for calculating NDVI is:

$$
\begin{aligned}
& \text { NDVI }=(\text { Float }(\ll B 8 ») \text { Float }(\ll B 4 »)) /(\text { Float }(\ll B 8 »)+ \\
& + \text { Float }(\ll \text { B4 })) \text {. }
\end{aligned}
$$

Using the Classification tool, for a convenient interpretation of the resulting NDVI raster surface, it is necessary to classify it according to the standard scale of values:

$0.2 \div+0.2$ water, artificial materials, clouds;

$0.21 \div 0.4$ open the soil, swamps

$0.41 \div 0.5$ meadows;

$0.51 \div 0.6$ forest belts, pastures;

$0.61 \div 0.8$ dense vegetation, forest.

In the third block of the model, a sequence of operations for the development of a vector map within the catchment area of the research object is presented. Based on high-resolution satellite images obtained free of charge in the navigation program SAS.Planet and the NDVI raster surface modeled in the second block, it is necessary to digitize the elements of the electronic map of the research object. To do this, the ArcGIS 9.2 tools are used, namely the Editor tools, and the NDVI scale. The mandatory elements of the map must be the digitized river, industrial facilities, settlements, 
agricultural land, and other objects of natural resources that are within the simulated catchment area. The digitization of the objects of the electronic map in the future will make it possible to calculate their areas.

According to the previously given methodology for determining the contribution of nutrients from housing and communal services, it is not the areas of the latter that are needed, but the number of people who live in them. Statistical data on the population permanently residing in villages do not always correspond to real data. Therefore, it is necessary to clarify the number of residents. For this purpose, according to the developed electronic map, the digitized areas of settlements using the Jacobs Crowd Formula [32] should be divided into equal squares and several reference ones should be selected. On the reference squares, it is necessary to calculate the number of residential buildings, take them as the average number, and then multiply by the number of certain squares. The given method will allow to calculate the approximate number of residential buildings, and, taking the average number of people who live in each house, to establish an approximate population within the research catchment area.

\section{Assessment of biogenic soil pollution using geoecological approaches}

5. 1. Results of obtaining initial geodata for calculating the balance of nutrients using geoinformation technologies

As shown in Fig. 2 with a graphical model, first of all, the initial data were obtained for calculating the balance of nutrients within the research drainage basin of the Oril River (Petrykivka district of the Dnipropetrovsk region).
The water intake area of the experimental site was built, and in Fig. 3 sequentially shows the intermediate and final results of this modeling, provides ample opportunities for hydro-ecological analysis. So, relying on certain limits of the catchment area, it becomes possible to calculate the total runoff of surface and groundwater into the river from agricultural land, enterprises, residential and commercial buildings located on the territory of the calculated catchment area.

As a result of the execution of the II block of the graphical model shown in Fig. 2, the resulting raster surface NDVI is shown in Fig. 4. The surface of the NDVI allows to visually assess the density and intensity of vegetation, in particular forest crops (deciduous and coniferous species). With its help, it is possible to assess the territorial location of farmland and open ground without dividing it into subordination to certain landowners and users (forestries, village councils, etc.). On the developed raster surface of the NDVI, built-up zones are visually distinguished, zones covered with vegetation of the corresponding intensity, and the absence of any vegetation is indicated in red on the map.

The visual separation of the surface is modeled NDVI does not provide an idea of the boundaries of certain areas of nature use. Therefore, the next stage of the study is the development of a vector map of the modeled catchment area, as indicated in the III block of the graphical model shown in Fig. 2. This manipulation occurs by overlaying the NDVI raster surface, taking into account the classification according to the standard scale, on the vector map of the catchment area. The overlapping of vector and raster maps with subsequent digitalization of objects made it possible to determine at the time of the study the area of land of a certain type of nature management within the catchment area of the Oril River.

1. Filling false hollows

2. Determining the direction of flow

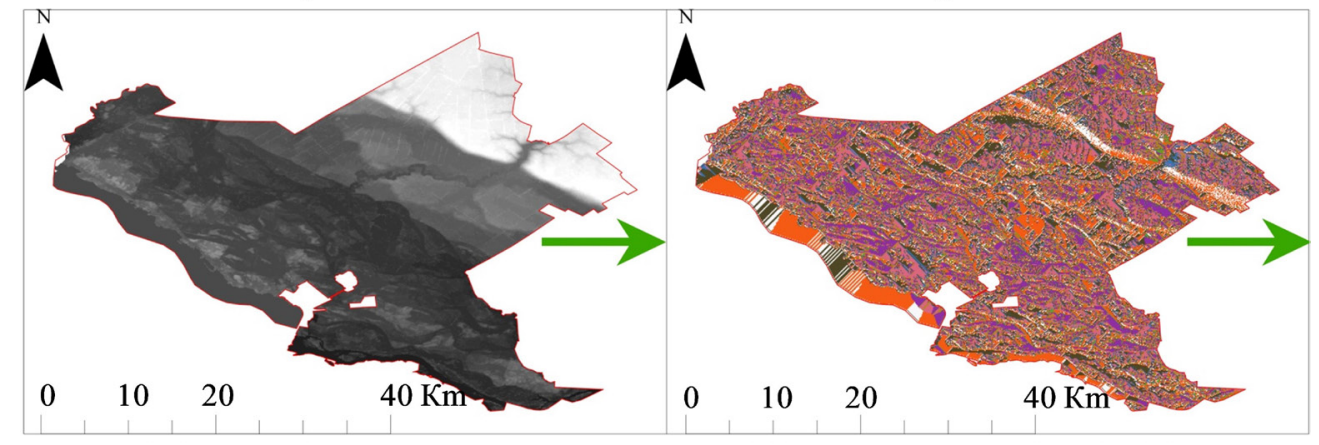

3. Reproduction of the total flow

4. River catchment model of Oril River

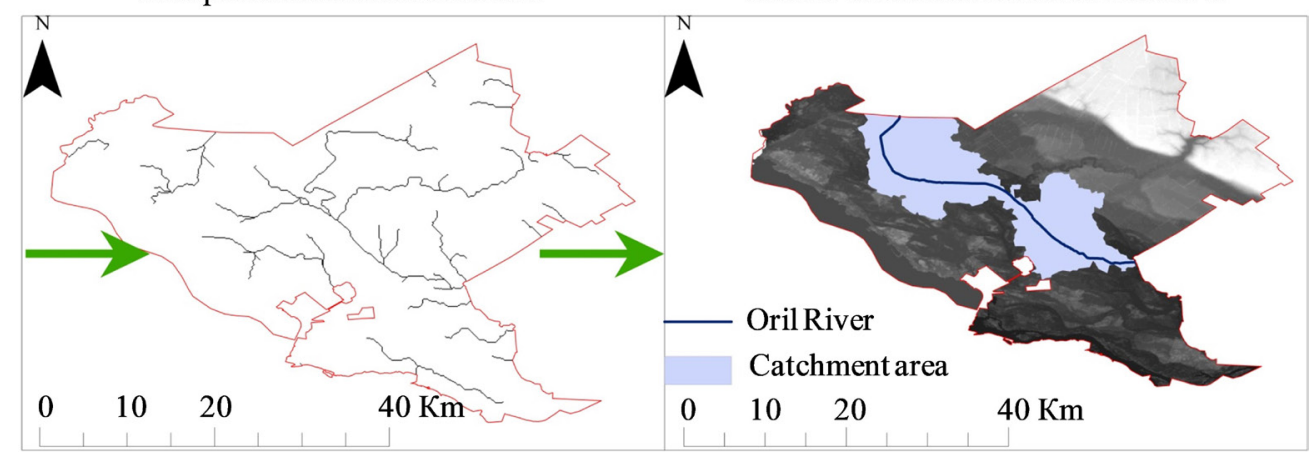

Fig. 3. The result of modeling the catchment area of the Orel River (Petrykivka district of Dnipropetrovsk region, Ukraine) 


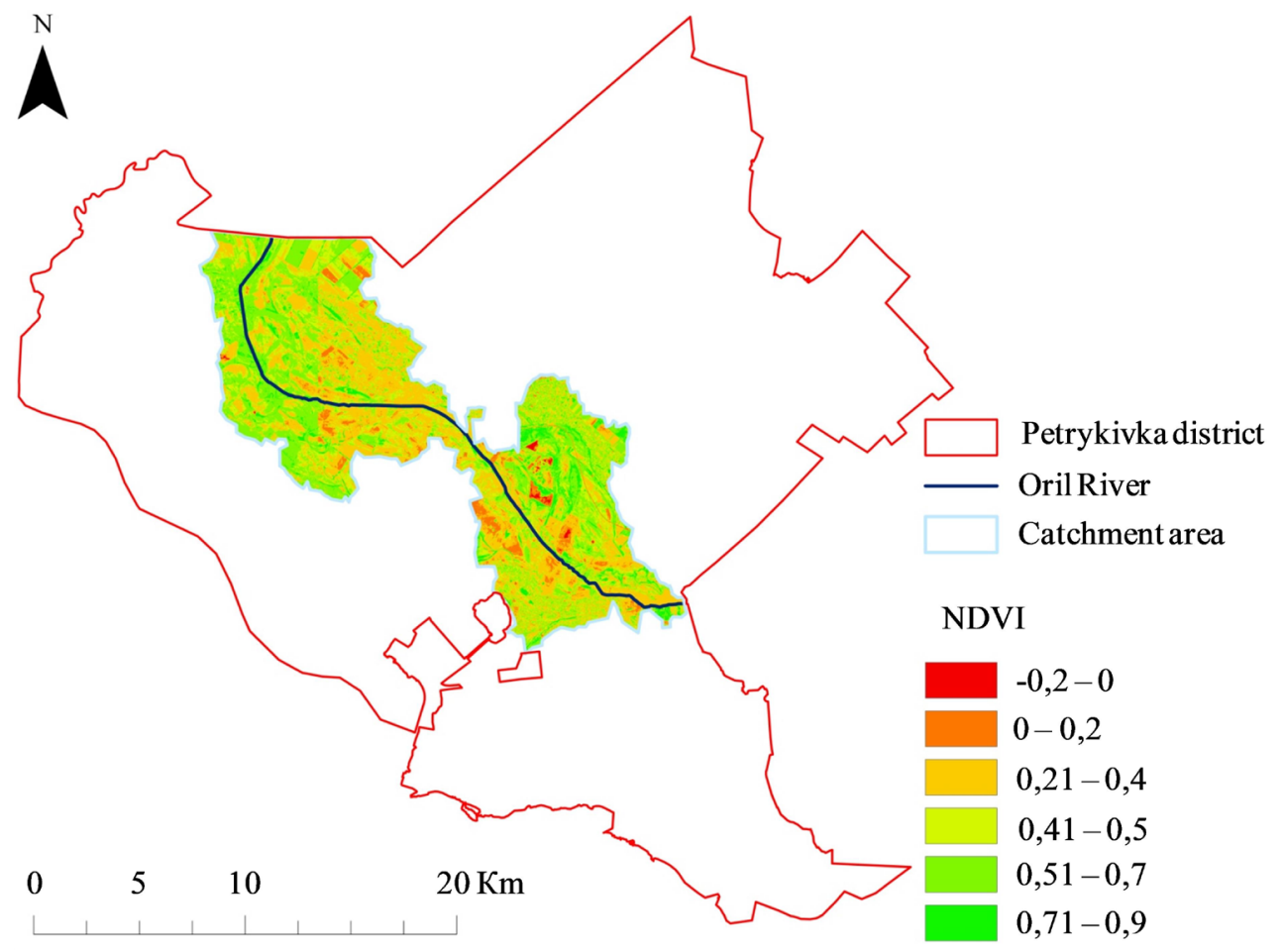

Fig. 4. Map of the raster surface NDVI of the catchment area of Oril River (Petrykivka district of Dnipropetrovsk region, Ukraine)

So, to obtain the initial data for calculating the balance of nutrients, a vector map of the simulated catchment area of the Oril River within the Petrykivka district of the Dnipropetrovsk region, shown in Fig. 5. The map contains a linear tracing layer for the Oril River, as well as polygonal layers of the real boundaries of settlements, agricultural fields, swamps, meadows, pastures, forest belts, forest lands. The advantage of the developed vector map is not only the ability to visualize spatial data like raster maps. The vector map toolkit allows to create a database about each individual map object, including land areas, as shown in Table 2 are required for the following balance calculations. A database has been formed that allows for mathematical processing of the data obtained, their statistical and spatial analysis.

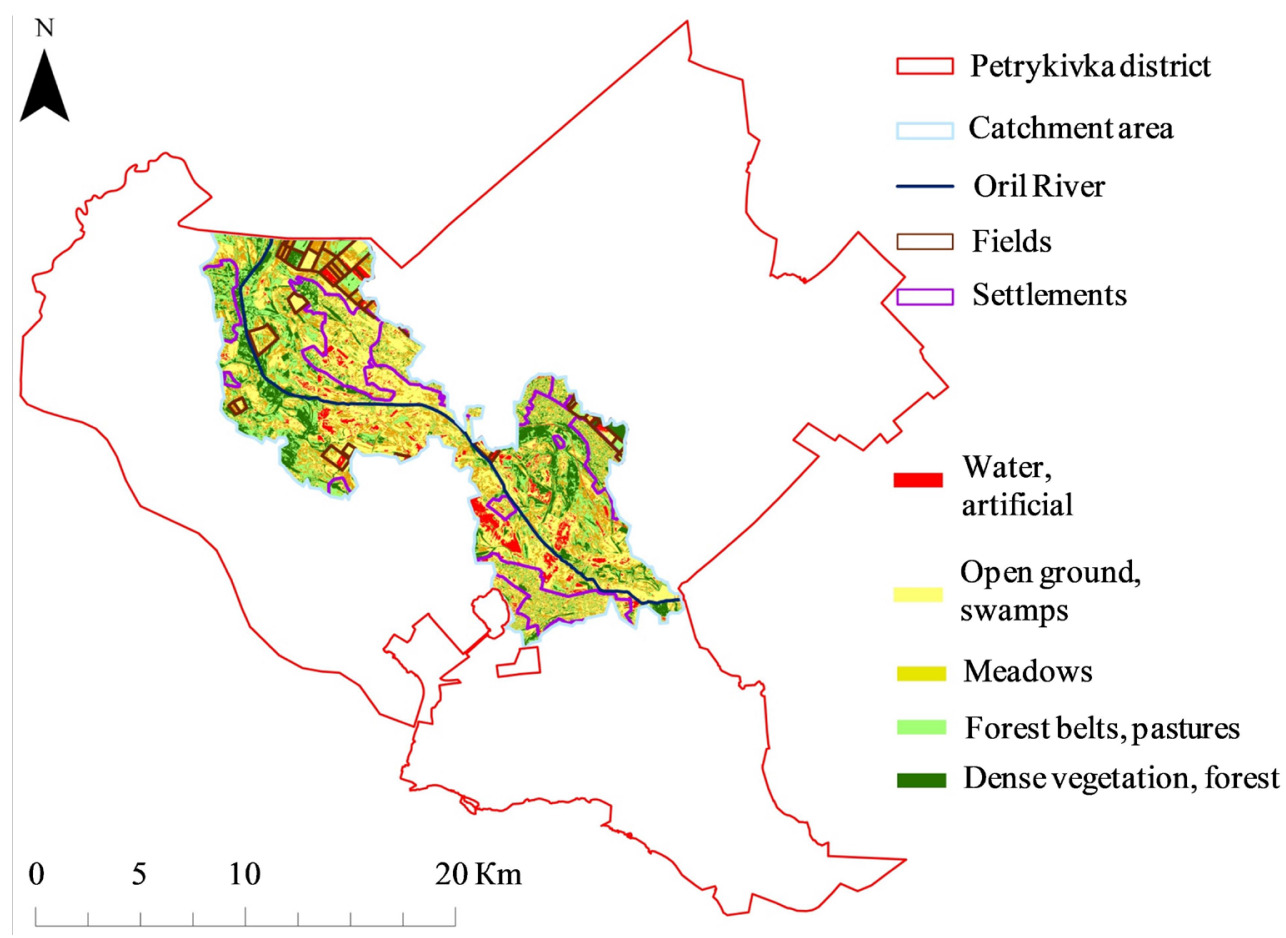

Fig. 5. Vector map of the modeled catchment area of Oril River (Petrykivka district of Dnipropetrovsk region, Ukraine) 
Table 2 study area (corn for grain, sunflower, winter wheat, spring

Distribution of the catchment area of the Oril River (Petrykivka district of Dnepropetrovsk region, Ukraine)

\begin{tabular}{|c|c|c|}
\hline Name of the object & $\begin{array}{c}\text { Area within the } \\
\text { catchment area, ha }\end{array}$ & $\begin{array}{c}\text { Percentage distri- } \\
\text { bution of areas, \% }\end{array}$ \\
\hline Total catchment area & $39,713.9$ & 100 \\
\hline 1. Area of settlements & 8,948 & 22.5 \\
\hline 2. Area of agricultural fields & $3,451.9$ & 8.7 \\
\hline $\begin{array}{c}\text { 3. Area of bogs overgrown } \\
\text { with reeds }\end{array}$ & 372.7 & 0.9 \\
\hline 4. Area of meadows & 3,355 & 8.4 \\
\hline 5. Area of forest belts, pastures & $4,131.5$ & 10.4 \\
\hline 6. Forest area & $2,753.9$ & 6.9 \\
\hline 7. Other objects & $16,700.9$ & 42.1 \\
\hline
\end{tabular}

Thus, using geoinformation methods, initial data were obtained for calculating the balance of nutrients within the research drainage area. In particular, the boundaries of the catchment area of the Oril River, Petrykivka district of the Dnipropetrovsk region, have been established, the area of which is 39.7 thousand hectares. It also clarified the boundaries and areas of settlements, farmland and land of a different type of nature management (meadows, pastures, forest belts, forest lands) and other objects falling within the catchment area.

According to the Table 2, a significant area of the drainage area is occupied by other objects. These, according to the standard scale of NDVI values, include water, artificial materials (road surface, individual buildings outside settlements and industrial reception facilities, etc.) and cloudiness on multispectral satellite images. Also, this category of objects includes lands that were illegally plowed up and were not taken into account in the calculations.

5. 2. Results of refined balance calculations of soil biogenic pollution using geoecological approaches

The balance of nutrients in the soils in the studied catchment area was calculated using formulas (2)(5). The calculation results are shown in Table 3.

Table 3

The results of calculating the balance amount of nutrients in soils within the catchment area of Oril River, Petrykivka district of the Dnipropetrovsk region, $t /$ year

\begin{tabular}{|c|c|c|c|c|}
\hline \multirow{2}{*}{$\begin{array}{c}\text { Ecosystem compo- } \\
\text { nents }\end{array}$} & \multicolumn{2}{|c|}{$\begin{array}{c}\text { Introduction of a } \\
\text { nutrient into the } \\
\text { ecosystem }\end{array}$} & \multicolumn{2}{c|}{$\begin{array}{c}\text { Removal of a } \\
\text { nutrient from the } \\
\text { ecosystem }\end{array}$} \\
\cline { 2 - 5 } & $N$ & $P$ & $N$ & $P$ \\
\hline farmland & $13,969.83$ & $10,745.76$ & $5,296.32$ & $2,158.59$ \\
\hline Industrial facilities & 0.0150 & 0.0099 & 0.0029 & 0.0017 \\
\hline $\begin{array}{c}\text { Objects of housing } \\
\text { and communal } \\
\text { services }\end{array}$ & 1.520 & 1.186 & 1.250 & 0.750 \\
\hline Natural factors & - & - & - & 236.0 \\
\hline Total & $13,971.36$ & $10,746.95$ & $5,297.57$ & $2,395.34$ \\
\hline $\begin{array}{c}\text { Balance sheet } \\
\text { difference }\end{array}$ & $+8,673.79$ & $+8,351.61$ & 0 & 0 \\
\hline
\end{tabular}

The component of the balance of nutrients from the contribution of agricultural land (Table 3 ) was calculated by formula (2) using:

- data of the Department of Agroindustrial Development of the Petrykivka District State Administration on the list and volumes of agricultural crops grown within the barley, soybeans and winter rye) for 2019,

- specified by the results of spatial modeling of agricultural land areas within the catchment area, is 3,451.9 hectares,

- data of operational reporting on the progress of harvesting crops in all categories of farms in Petrykivka District for 2019.

The calculated results are valid for 40 officially operating agricultural lands used in the research. The calculations do not take into account illegally plowed lands and household plots of the population, on which mineral and organic fertilizers are applied.

According to calculations carried out according to formula (2), it was found that within the studied catchment area of the Oril River, 14.0 and 10.7 thousand tons/year of nitrogen and phosphorus are applied with mineral fertilizers, respectively, which in the overwhelming volume are deposited in soils, as indicated in Fig. 6.

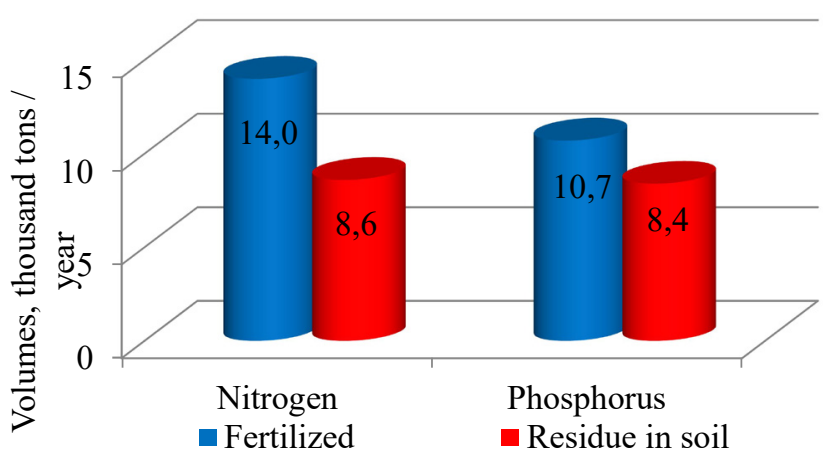

Fig. 6. Balance amounts of biogenic substances introduced as part of mineral fertilizers and remain in the soil within the catchment area of Oril River (Petrykivka district of Dnipropetrovsk region, Ukraine)

The component of the balance of nutrients from the contribution of industrial facilities (Table 3) was calculated using the formula (3). According to the conducted spatial analysis, it was found that within a certain catchment area of the Oril River on the territory of the Petrykivka district, there is only one enterprise - Petrykivka Fish farm CJSC, which uses the water resources of the district. The volume of used in 2019 surface waters from the river. Orel by this enterprise is 4996.6 thousand $\mathrm{m}^{3}$ /year. The concentration of nitrogen and phosphorus in the natural waters of the Oril River is $0.6 \mathrm{mg} / \mathrm{l}$ and $0.34 \mathrm{mg} / \mathrm{l}$, respectively. The concentration of nitrogen and phosphorus in wastewater according to the standards for fish farms is $3 \mathrm{mg} / \mathrm{l}$ and $2 \mathrm{mg} / \mathrm{l}$, respectively.

The obtained calculation results are valid on the basis of one officially operating enterprise, information about which was used in the research. The calculations do not take into account illegal or temporarily operating enterprises, for example, the State Enterprise "Dnipropetrovsk Oblavtodor".

The component of the balance of biogenic elements from the contribution of objects of housing and communal services (Table 3) was calculated using the formula (4). To determine the number of people living within the study site, the number of residential buildings was first determined using the Jacobs Crowd Formula [32]. The processed Cosmos image is applied, which is divided into equal squares. Then several reference squares were selected, for which the number of houses was calculated. The results obtained are 
averaged and multiplied by the number of squares. Thus, the approximate number of residential buildings has been established. Taking into account the fact that on average up to 3 people live in each house, an approximate population has been established in the experimental territory. It is estimated that the population within the modeled catchment area of Orel River is 4,282 people. The potential concentration of nutrients from one person is: nitrogen $-0.355 \mathrm{~kg} /$ year, phosphorus $-0.277 \mathrm{~kg} /$ year [7].

Local residents use underground waters for household purposes, the concentration of nutrients in them is: nitrogen - $5 \mathrm{mg} / \mathrm{l}$; phosphorus $-3 \mathrm{mg} / \mathrm{l}$. The rate of water consumption and the coefficients of unevenness depend on the size of the settlement [7] and within the research area fluctuate within the range of $50 \div 180 \mathrm{l} /$ day.

The component of the balance of biogenic elements, in particular phosphorus, from the contribution of natural factors (Table 3) was calculated using the formula (5).

According to the obtained results of calculating the balance of nutrients in soils within the studied catchment area, given in Table 3, it was found that the amounts of introduced nutrients overlap over those taken out of the ecosystem. At the same time, agricultural land is the main component of the ecosystem in the cycle of nitrogen and phosphorus. For the investigated catchment area of the Oril River, Petrykivka district of Dnipropetrovsk region, the fate of industrial facilities and housing and communal services is scanty. Natural factors taken into account for this ecosystem and present in the negative component of the balance and amounting to about $10 \%$ of the total removal of phosphorus from the ecosystem will not balance the balance components. However, unlike nitrogen, they reduce the accumulation of phosphorus in soils, determined from the results of calculating the balance of biogenic elements, according to the proposed methodology using geoecological approaches and calculated according to formula (1).

Thus, the results of the calculation indicate that for the year within the simulated catchment area of the Oril River, Petrykivka district of Dnipropetrovsk region, residual nitrogen and phosphorus accumulate 8.6 thousand tons and 8.4 thousand tons, respectively.

\section{Discussion of the results of the assessment of soil biogenic pollution for ecologically safe sustainable development of ecosystems}

The proposed method for calculating the balance of nutrients makes it possible to determine not only quantitative indicators (Table 3). It allows to determine the impact of each component of the ecosystem on the overall redistribution of balance components. That is, to point out the priority sources of nutrient input into ecosystems. According to the proposed method for obtaining the initial geodata using geoinformation technologies, the area of agricultural land is less than $10 \%$ of the total area of the investigated catchment area, as shown in Table 2. However, it is agricultural activity that makes the greatest contribution to the pollution of this ecosystem, as evidenced by the results of refined balance calculations of soil biogenic pollution using geoecological approaches.

Analyzing the results of the calculations, it was found that almost $99 \%$ of nitrogen and phosphorus goes to the soils of the research drainage area of the Oril River from ag- ricultural activities. In accordance with the initial geodata of the balance equations, a significant amount of nutrient residues in soils is due to an excess of mineral fertilizers applied to farmland. This fact is confirmed by comparing the volumes of mineral fertilizers applied to agricultural land and the residual amount of nutrients in the soils. Form Fig. 6 it follows that, within the studied catchment area of the Oril River, plants assimilate only $40 \%$ and $20 \%$ of nitrogen and phosphorus, respectively.

According to a preliminary assessment of the research results, it can be argued that the improved methodology for geoecological assessment of soil biogenic pollution using information technologies provides updated results for calculating the amount of nutrient residues in soils. And the volumes of nitrates and phosphates obtained by applying geoecological approaches accumulate in soils, indicate the sources of their entry into ecosystems, as evidenced by the results of Table 3 .

Summarizing the results of the geoecological assessment of soil biogenic pollution using information technologies, it can be argued that the proposed principles are appropriate for any aquatic ecosystems experiencing anthropogenic impact. The use of geodata from satellite satellite images allows monitoring observations according to the proposed methodology for objects of significant area (hundreds thousands of hectares) - reservoirs of small rivers, settlements, administrative districts. Not allowing to estimate with the same high accuracy the accumulation of nutrients in the soils of the basins of large rivers, large in area of natural or anthropogenic objects (area of more than tens of thousands of hectares). That is, with an increase in the areas covered for the calculation of territories, the correctness of the results obtained is lost.

Modeling the catchment area and taking into account geoecological approaches, allows for a more accurate calculation of the amount of nitrogen and phosphorus that remains in the soil, rather than being absorbed by plants and not leaving the ecosystems. Due to the simplicity of obtaining geodata, the proposed method can be adapted for other mono-ecosystems, in the cycle of which biogenic elements are present, for example, purely for urban systems, or industrial facilities. Since the digital elevation model of the Earth and multispectral satellite images are freely available for all cells of the planet, which are constantly being updated and improved.

It should be noted that the balance calculations of soil biogenic pollution must be updated annually, regardless of the size of ecosystems, since the results obtained are valid for the conditions taken into account at the time of research within the study area, that is:

- crop rotation and area of cultivation of agricultural crops, the volume of the harvested crop, the amount of mineral fertilizers,

- the volumes and concentrations of natural and discharged waste waters used by industrial enterprises located within the study area,

- the number of inhabitants of settlements and the volume of water supply to the population within the study area,

- the area and type of nature management of the catchment area, which is associated with crop rotation of farmland, the quality of forest land and the degree of afforestation and landscaping of the territory.

However, it is necessary to take into account the presence of the components of the water balance, proposed 
in the graphical model for obtaining the initial data for calculating the balance of nutrients using geoinformation methods (Fig. 2). It is also necessary, on the basis of the developed maps and statistical information about the ecosystem, to carry out calculations of the water balance, taking into account geoecological approaches.

Obtaining statistical information on industrial (discharges of nutrients into water bodies, storage of industrial waste on the territory of enterprises, etc.) and agricultural (amount of fertilizers used, crop rotation, etc.) production, in particular, is private. However, the official area of land used in various sectors of the national economy is freely available to the State Land Cadastre. However, there is no publicly available information on lands of other categories of nature use, including their illegal use. Therefore, the advantages of the proposed approach to obtaining geodata using information technologies are obtaining data that are generally absent in the State Land Cadastre, as well as the possibility of their refinement at the time of monitoring observations.

The boundaries of the modeled catchment area remain statically unchanged, but digital elevation model monitoring is required to refine their boundaries. To clarify the areas and type of nature management within the study area, it is necessary to carry out monitoring observations of multispectral images. It should be noted that these monitoring studies are less labor and material costly than the classical methods of monitoring observations of soil pollution. Therefore, the application of the proposed methods of geoecological assessment greatly facilitates the observation of nitrogen and phosphorus pollution not only of agricultural land, but also of other types of land use.

Therefore, the carried out balance calculations using information technologies will allow the further implementation of the precision farming system, which is based on the use of a complex of satellite and information technologies. This makes it possible to accurately calculate the amount of applied fertilizers and other resources with high accuracy for each section of the field. After processing satellite and laboratory data, a point map of the field is created with an indication of its characteristics. This will contribute to the rational distribution of mineral fertilizers, avoidance of excess use and increase the productivity of farmland. With significant distribution, this approach will reduce the cost of producing a unit of output and increase the profitability of agricultural production.

On the basis of the developed graphic model (Fig. 2) with the use of Earth remote sensing methods, it becomes possible to obtain initial data for the balance calculations of other substances that accumulate in soils, for example, heavy metals, radioactive elements.

A promising direction for improving the proposed methodology is to obtain initial geodata to determine the catchment area and clarify the distribution of lands by categories of nature management using unmanned aerial vehicles (UAVs). The use of UAVs will allow obtaining high-precision and up-to-date Geodata of the necessary, even a small research object (separate forest and agricultural lands, industrial enterprises, etc.). Based on the results of such geodata, it is possible to obtain highly accurate balance calculations and minimize the imperfections of the proposed method.
Thus, the proposed method is not final and should be improved as it is applied. Now the imperfection of the methodology is the problem of obtaining statistical information necessary for calculations. Initial statistical data are not always needed for calculations, they can be obtained from official sources, or their reliability is questionable. Therefore, the results of calculating the water balance of biogenic elements according to the proposed methodology should be compared with the results of selective laboratory studies, carry out corrective recalculations, introduce additional coefficients, and the like. However, the results of long-term monitoring observations of the balance of biogenic substances, taking into account geodata, will provide an opportunity to predict the further accumulation of the studied substances in the soil.

Consequently, the assessment of biogenic soil pollution using geoinformation technologies makes it possible to optimize the use of mineral fertilizers for agricultural producers, reduce the burden on the environment and predict environmentally safe sustainable development of ecosystems.

\section{Conclusions}

1. It is proposed to use geodata to calculate the balance of nutrients, which are based on a digital elevation model, high-resolution satellite images and multispectral satellite images. Output geodata is recommended to be processed using geoinformation technologies and tools of the ArcGIS Desktop software. Using the method of obtaining the initial geodata, the catchment area of the Oril River within the Petrykivka district of the Dnipropetrovsk region is constructed. It is established that the boundaries and the total area of the catchment area,is 39.7 thousand hectares. Boundaries and areas of settlements, agricultural and forest lands and lands of other types of nature management are clarified (meadows, pastures, forest belts, etc.).

2. It is proposed to take into account the balance components (runoff from agricultural land, industrial enterprises, housing and communal services, as well as natural migration of nutrients) taking into account the belonging to the catchment area. This clarification indicates the territorial contribution of the objects belonging to the catchment area. According to refined calculations, it was determined that in 2019, within the simulated catchment area of the Oril River, 8.6 thousand tons and 8.4 thousand tons of nitrogen and phosphorus, respectively, were accumulated in soils.

According to the conducted geoecological assessment of soil pollution, it was found that farmland occupies less than $10 \%$ of the total area of the catchment area, while making the greatest contribution to the biogenic pollution of the ecosystem. The calculations made it possible to conclude that in the study area, biogenic elements in soils are accumulated due to the excessive use of mineral fertilizers. It has been substantiated that the application of the proposed geoecological assessment makes it possible to obtain the results of the adjusted volumes of nitrogen and phosphorus accumulation in soils and indicates the sources of their input. It has been concluded that the application of the proposed approaches in the practice of environmental monitoring will contribute to tracking the introduction of nutrients into ecosystems and will reduce the load on the environment. 


\section{References}

1. Yuan, Z., Shi, J., Wu, H., Zhang, L., Bi, J. (2011). Understanding the anthropogenic phosphorus pathway with substance flow analysis at the city level. Journal of Environmental Management, 92 (8), 2021-2028. doi: https://doi.org/10.1016/j.jenvman.2011.03.025

2. Camargo, J. A., Alonso, Á. (2006). Ecological and toxicological effects of inorganic nitrogen pollution in aquatic ecosystems: A global assessment. Environment International, 32 (6), 831-849. doi: https://doi.org/10.1016/j.envint.2006.05.002

3. Hansen, B., Thorling, L., Schullehner, J., Termansen, M., Dalgaard, T. (2017). Groundwater nitrate response to sustainable nitrogen management. Scientific Reports, 7 (1). doi: https://doi.org/10.1038/s41598-017-07147-2

4. Manuel, J. (2014). Nutrient Pollution: A Persistent Threat to Waterways. Environmental Health Perspectives, 122 (11). doi: https://doi.org/10.1289/ehp.122-a304

5. Yao, X., Zhang, Y., Zhang, L., Zhou, Y. (2018). A bibliometric review of nitrogen research in eutrophic lakes and reservoirs. Journal of Environmental Sciences, 66, 274-285. doi: https://doi.org/10.1016/j.jes.2016.10.022

6. Lewis, W. M., Wurtsbaugh, W. A., Paerl, H. W. (2011). Rationale for Control of Anthropogenic Nitrogen and Phosphorus to Reduce Eutrophication of Inland Waters. Environmental Science \& Technology, 45 (24), 10300-10305. doi: https://doi.org/10.1021/ es202401p

7. Yatsyk, A. V., Hryshchenko, Yu. M., Volkova, L. A., Pasheniuk, I. A. (2007). Vodni resursy: vykorystannia, okhorona, vidtvorennia, upravlinnia. Kyiv: Heneza, 360.

8. Natsionalna dopovid pro yakist pytnoi vody ta stan pytnoho vodopostachannia v Ukraini u 2018 rotsi (2019). Ministerstvo rehionalnoho rozvytku, budivnytstva ta zhytlovo-komunalnoho hospodarstva Ukrainy. Kyiv. Available at: https://www.minregion. gov.ua/wp-content/uploads/2019/11/Proekt-Nats.-dop.-za-2018.pdf

9. Sala, L., Mujeriego, R. (2001). Cultural eutrophication control through water reuse. Water Science and Technology, 43 (10), 109-116. doi: https://doi.org/10.2166/wst.2001.0595

10. Hakeem, K. R., Sabir, M., Ozturk, M., Akhtar, M. S., Ibrahim, F. H. (2016). Nitrate and Nitrogen Oxides: Sources, Health Effects and Their Remediation. Reviews of Environmental Contamination and Toxicology, 183-217. doi: https://doi.org/10.1007/398_2016_11

11. Ahmed, M., Rauf, M., Mukhtar, Z., Saeed, N. A. (2017). Excessive use of nitrogenous fertilizers: an unawareness causing serious threats to environment and human health. Environmental Science and Pollution Research, 24 (35), 26983-26987. doi: https:// doi.org/10.1007/s11356-017-0589-7

12. Lawniczak, A. E., Zbierska, J., Nowak, B., Achtenberg, K., Grześkowiak, A., Kanas, K. (2016). Impact of agriculture and land use on nitrate contamination in groundwater and running waters in central-west Poland. Environmental Monitoring and Assessment, 188 (3). doi: https://doi.org/10.1007/s10661-016-5167-9

13. Malovanyi, M. S., Havryliak, M. Ya., Nedal Khussein Musalam Al Khasanat (2009). Mozhlyvosti ekolohichno bezpechnoho vykorystannia mineralnykh dobryv. Ekolohichna bezpeka, 3 (7), 31-37. Available at: http://www.kdu.edu.ua/EKB_jurnal/ 2009_3(7)/PDF/31.PDF

14. Mollenhauer, H., Kasner, M., Haase, P., Peterseil, J., Wohner, C., Frenzel, M. et. al. (2018). Long-term environmental monitoring infrastructures in Europe: observations, measurements, scales, and socio-ecological representativeness. Science of The Total Environment, 624, 968-978. doi: https://doi.org/10.1016/j.scitotenv.2017.12.095

15. Ellingsen, K. E., Yoccoz, N. G., Tveraa, T., Hewitt, J. E., Thrush, S. F. (2017). Long-term environmental monitoring for assessment of change: measurement inconsistencies over time and potential solutions. Environmental Monitoring and Assessment, 189 (11). doi: https://doi.org/10.1007/s10661-017-6317-4

16. Wang, N., Mao, L., Huang, H. B., Zhang, J. Z., Zhou, P. (2012). Temporal and spatial variation of non-point source nitrogen in surface water in urban agricultural region of Shanghai. Huan Jing Ke Xue, 33 (3), 802-809. Available at: https://pubmed.ncbi.nlm. nih.gov/22624371/

17. Bartley, R., Speirs, W. J., Ellis, T. W., Waters, D. K. (2012). A review of sediment and nutrient concentration data from Australia for use in catchment water quality models. Marine Pollution Bulletin, 65 (4-9), 101-116. doi: https://doi.org/10.1016/ j.marpolbul.2011.08.009

18. Shen, Z., Qiu, J., Hong, Q., Chen, L. (2014). Simulation of spatial and temporal distributions of non-point source pollution load in the Three Gorges Reservoir Region. Science of The Total Environment, 493, 138-146. doi: https://doi.org/10.1016/ j.scitotenv.2014.05.109

19. Reymers, N. F. (1990). Prirodopol'zovanie. Moscow: Mysl', 637.

20. Xu, H.-S., Xu, Z.-X., Liu, P. (2013). Estimation of nonpoint source pollutant loads and optimization of the best management practices (BMPs) in the Zhangweinan River basin. Huan Jing Ke Xue, 34 (3), 882-891. Available at: https://pubmed.ncbi.nlm.nih. gov/2374539/

21. Pinto, C. C., Calazans, G. M., Oliveira, S. C. (2019). Assessment of spatial variations in the surface water quality of the Velhas River Basin, Brazil, using multivariate statistical analysis and nonparametric statistics. Environmental Monitoring and Assessment, 191 (3). doi: https://doi.org/10.1007/s10661-019-7281-y

22. Bresciani, M., Vascellari, M., Giardino, C., Matta, E. (2012). Remote sensing supports the definition of the water quality status of Lake Omodeo (Italy). European Journal of Remote Sensing, 45 (1), 349-360. doi: https://doi.org/10.5721/eujrs20124530 
23. Wang, X., Yang, W. (2019). Water quality monitoring and evaluation using remote sensing techniques in China: a systematic review. Ecosystem Health and Sustainability, 5 (1), 47-56. doi: https://doi.org/10.1080/20964129.2019.1571443

24. Arheimer, B., Andersson, L., Larsson, M., Lindström ,G., Olsson, J., Pers, B. C.( 2004). Modelling diffuse nutrient flow in eutrophication control scenarios. Water Sci Technol., 49 (3), 37-45. URL: https://pubmed.ncbi.nlm.nih.gov/15053097/

25. Cherry, K. A., Shepherd, M., Withers, P. J. A., Mooney, S. J. (2008). Assessing the effectiveness of actions to mitigate nutrient loss from agriculture: A review of methods. Science of The Total Environment, 406 (1-2), 1-23. doi: https://doi.org/10.1016/ j.scitotenv.2008.07.015

26. SRTM (TSMR) Dnepropetrovskoy oblasti. Available at: https://mapgroup.com.ua/services/32-dem-ukraine/88-srtm-tsmrdnepropetrovskoj-oblasti

27. Science for a changing world. Available at: https://earthexplorer.usgs.gov/

28. Official site company ESRI. Available at: https://www.esri.com/ru-ru/arcgis/about-arcgis/overview

29. Gardiner, M. M., Burkman, C. E., Prajzner, S. P. (2013). The Value of Urban Vacant Land to Support Arthropod Biodiversity and Ecosystem Services. Environmental Entomology, 42 (6), 1123-1136. doi: https://doi.org/10.1603/en12275

30. Bazhan, O. H., Vortman, D. Ya. (2011). Petrykivka. Entsyklopediia istorii Ukrainy. Kyiv: Nauk. dumka, 183.

31. Rehionalna dopovid «Pro stan navkolyshnoho pryrodnoho seredovyshcha Dnipropetrovskoi oblasti v 2019 rotsi» (2020). Dnipropetrovsk, 321. Available at: https://adm.dp.gov.ua/storage/app/uploads/public/605/06f/47b/60506f47bd3cb255698190.pdf

32. Jacobs, A. H. (1967). To Count a Crowd. Columbia Journalism Review, 6, 36-40. 